\title{
Simulation of 7- Level AC-AC Sparse Modular Multilevel Converter
}

\author{
M. Anka Rao, R. Mayuri
}

\begin{abstract}
AC-AC Sparse modular multilevel converter (SMMC) is proposed in this paper. It is a bi-directional multilevel converter and it is employed in high power and high voltage applications. It contains full bridge and half bridge SM's on the middle arm, and low frequency converters on each side of the converter. In this converter more number of IGBT switches can work under soft switching mode. Control scheme is also proposed in this paper, it is utilized to obtain the capacitor voltage balancing. Capacitor voltages have some oscillations, harmonics will be decreased by applying modified PWM technique. Number of levels of the converter increases, voltage harmonics will be decreased and also switching frequency of the full bridge and half bridge arm IGBTs is decrease. The appropriateness of the 7-level AC/AC SMMC with Control scheme will be estimated by utilizing the MATLAB/SIMULINK software.
\end{abstract}

Index Terms-7-level AC/AC SMMC, Control design, Capacitor voltage balancing, Modified PWM technique.

\section{INTRODUCTION}

Now a days, multilevel converters have broad range of applications in many industrial applications such as FACTS devices, HVDC lines and renewable energy resource interfaces [1] - [3]. Multilevel converters can be categarised into three types. Those are diode clamped converter(DCC), Flying capacitor converter(FCC) and Cascaded $\mathrm{H}$ - bridge converter(HBC). If number of levels of the converter increases, there should be a complexity in capacitor voltage adjusting in DCC, FCC requires more number of capacitor and cascaded $\mathrm{H}$ - bridge converter requires more number of individual dc sources [5] - [6]. To overcome such limitations of the converters, modular multilevel converter (MMC) is proposed in 2003. MMC contains low voltage switches and offering the low harmonic distortions. Now a days, MMC [7] - [9] based HVDC systems are used for transmitting the power up to GW range. MMC is also have some drawbacks, i.e more number of IGBT switches can operate under hard switching mode and circulating current is also more. To overcome such limitations of MMC, a new bi-directional converter, i.e sparse modular multilevel Converter(SMMC) is proposed [10].

SMMC contains fewer number of components than compared with the other types of converter topologies. In this multilevel converter more number of IGBT switches can work under soft switching mode. In this proposed converter, by inserting the third harmonic frequencies the capacitor voltage gets balanced. FFT analysis for 5-level SMMC as shown in

M. Anka Rao, Assistant Professor, Dept. of EEE, JNTU College of engineering \& technology, Anantapur, Andhra Pradesh, India, 7702968080

R. Mayuri, PG Scholar, Dept. of EEE, JNTU College of engineering \& technology, Anantapur, Andhra Pradesh, India, 9110757420 fig.1.1. It gives the value for total harmonic distortion (THD). To reduce the THD value, levels of the converter has to be increased. To reduce the THD value, 7-level SMMC is used in place of 5-level SMMC. 7-level SMMC is explained with control scheme in the following sections.

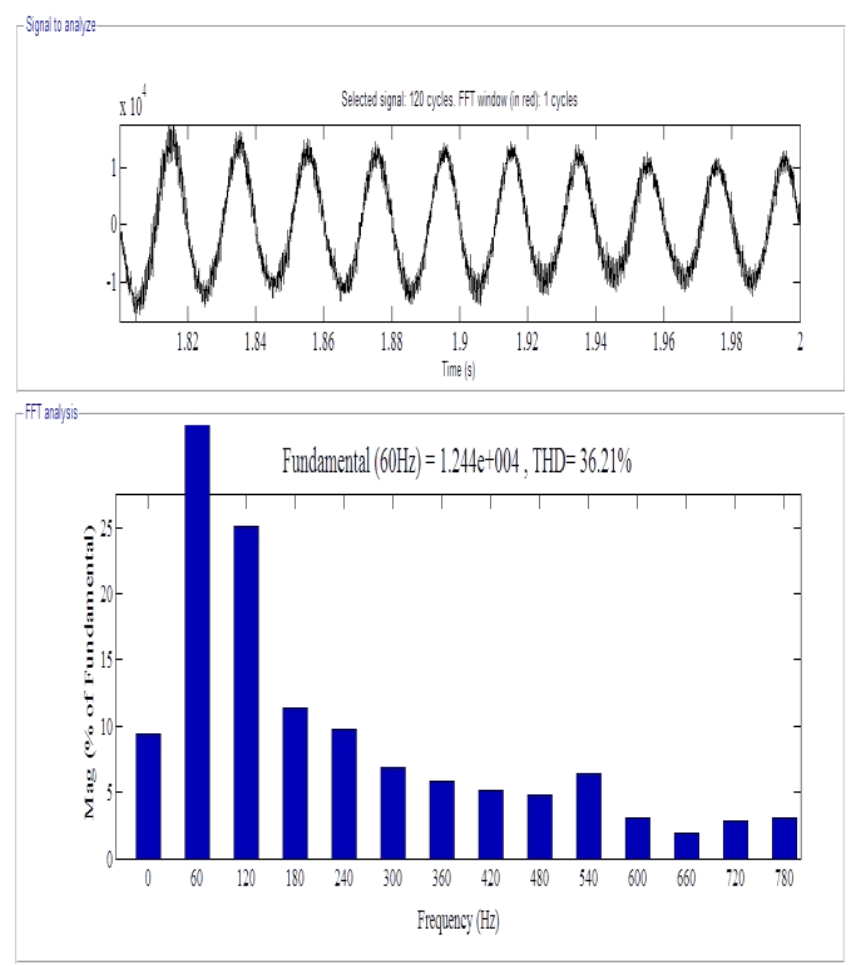

Fig.1.1 FFT analysis for 5-level SMMC

\section{7-LEVEL AC - AC SMMC}

Fig. 2.1 shows the circuit diagram of 1 - $\emptyset$ N-level AC/AC SMMC. Fig. 2.2 shows that circuit diagram of $1-\emptyset 7$-level AC/AC SMMC. It contains low frequency converter on each side, and middle arm contains three full bridge SM's on upper leg and three half bridge SM's on lower leg. By inserting the proper number of SM's in the lower and upper legs of the middle arm, the necessary voltage on the each side of the converter can be obtained. Fig. 2.3 shows that simplistic diagram of 3 - $\emptyset$ SMMC. No circulating current between different phases of 3 - $\emptyset$ SMMC, because they are separated from each other by a $3-\emptyset$ isolating transformer. Zero circulating current in the converter can be reduced by placing one reverse biased IGBT switch on each arm of the full bridge unfolder circuit. For higher number of levels, converter requires two or more reverse biased IGBT switches, on each arm of full bridge unfolder circuit. Both full bridge and half bridge unfolder circuits operate under zero voltage switching(ZVS) condition 


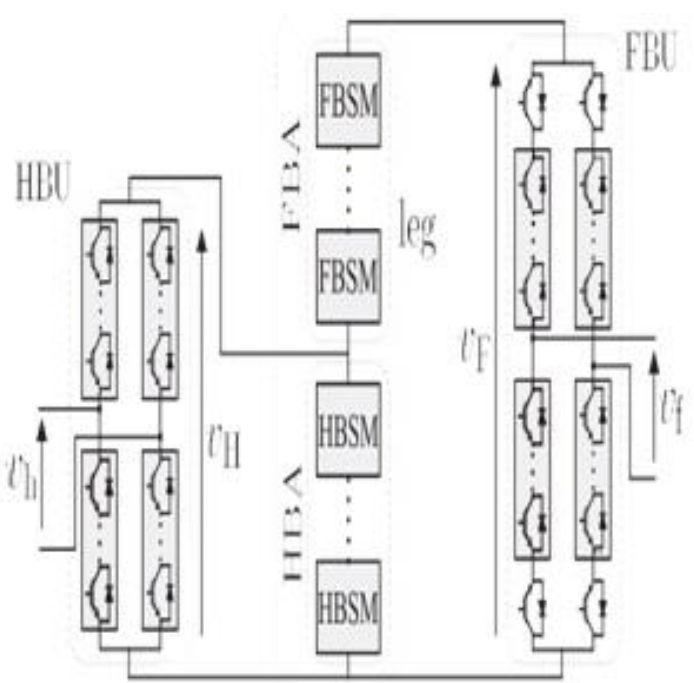

Fig. 2.1 Circuit diagram of $1-\emptyset \mathrm{N}$-level $S M M$

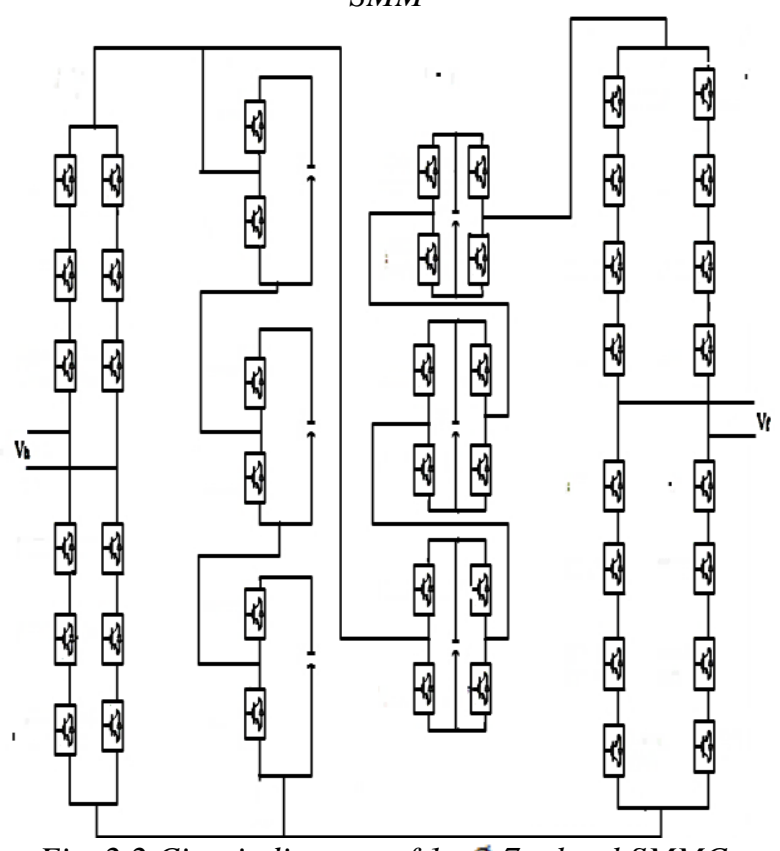

Fig. 2.2 Circuit diagram of 1 - $\emptyset 7$-level SMMC.

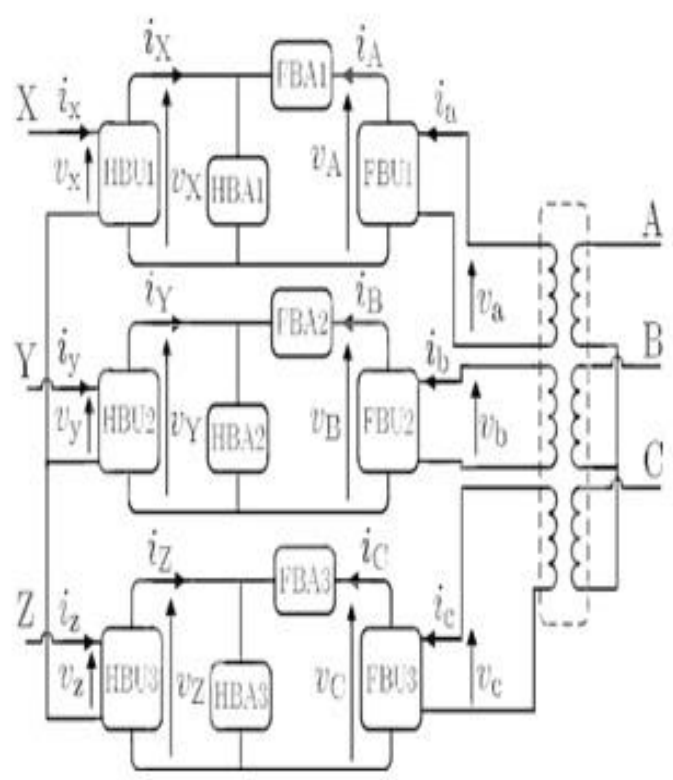

Fig. 2.3 Simplistic Diagram of 3 - $~ S M M C$

\section{CONTROL SCHEME FOR 7 - LEVEL SMMC}

Fig. 3.1 shows that block diagram of control design. The proposed 7-level AC/AC SMMC can be controlled by using abc-dq reference frame theory. In this reference theory, AC side current can be controlled by using phase locked loop(PLL) on each side of the converter. PLL is employed to attain the synchronization mechanism. Two reference generators provides the reference ac currents to the current controller.

$\mathrm{P}_{\text {aref }}$ in grid $\mathrm{A}$ - side, determines the magnitude and direction of active or true power transferred. In this proposed converter, true power flows from Grid - A side to Grid - B side. So, low frequency converter on the Grid - A side can act as a rectifier, while low frequency converter on the Grid - B side can acts as an inverter circuit. The injected true and reactive powers to the grid A and B are obtained from the equations (1) \& (2).

$\mathrm{P}=\frac{\mathrm{VV}_{\mathrm{s}}}{\mathrm{X}} \sin \delta$

$\mathrm{Q}=\frac{\mathrm{V}_{\mathrm{s}}^{2}-\mathrm{VV}_{\mathrm{s}} \cos \delta}{\mathrm{X}}$

Where $V$ and $V_{s}$ are the AC-side and grid voltages respectively, $\delta$ is the angle between the $\mathrm{AC}$ - side and grid-side voltages and $\mathrm{X}$ is the filter reactance. The reactive powers $Q_{a r e f}$ and $Q_{b r e f}$ are regulated to arbitrary values with in the ratings of the converter.

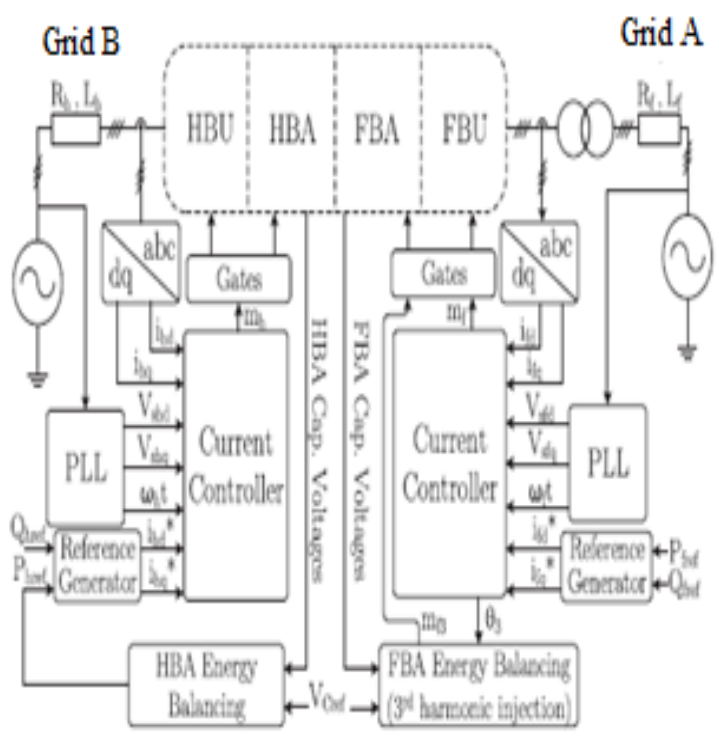

Fig. 3.1 Block diagram for control scheme

The proposed controlled scheme contains a current controller on the each side, which is used, to provide the expected true and reactive power interchange with the grid. Fig. 3.2 shows the block diagram for current controller. Current controller contains PI controller, which is employed to enhance the steady state response.

Harmonics and oscillations in the capacitor voltage waveform can be decreased by applying modified PWM technique to converter. By changing the energy stored in the half bridge and full bridge arm capacitors, balance between the AC-side power and arm power can be achieved. On the full bridge arm side, capacitor voltage balancing can be maintained by introducing the third harmonic voltages. 


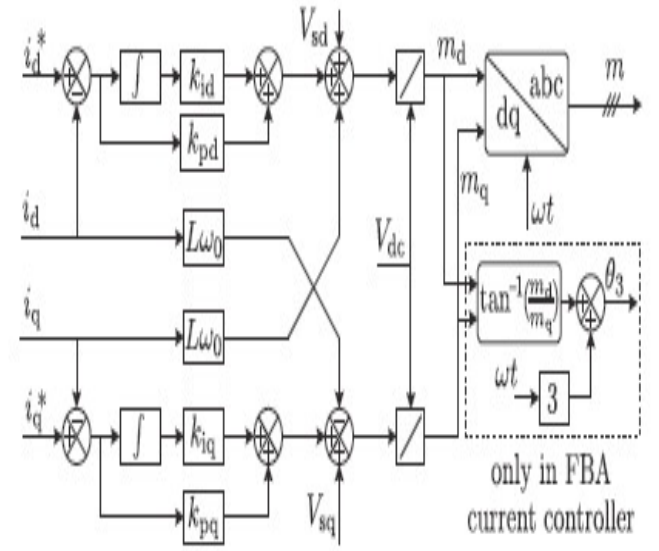

Fig. 3.2 Block diagram for current controller

\section{Simulation Results}

Fig. 4.1 shows that Simulink diagram of three phase 7- level SMMC. In this, Grid A operated at $50 \mathrm{HZ}$ frequency and Grid B operated at $60 \mathrm{HZ}$ frequency. Fig. 4.2 shows that Simulink diagram of subsystem that is single phase 7 - level SMMC.

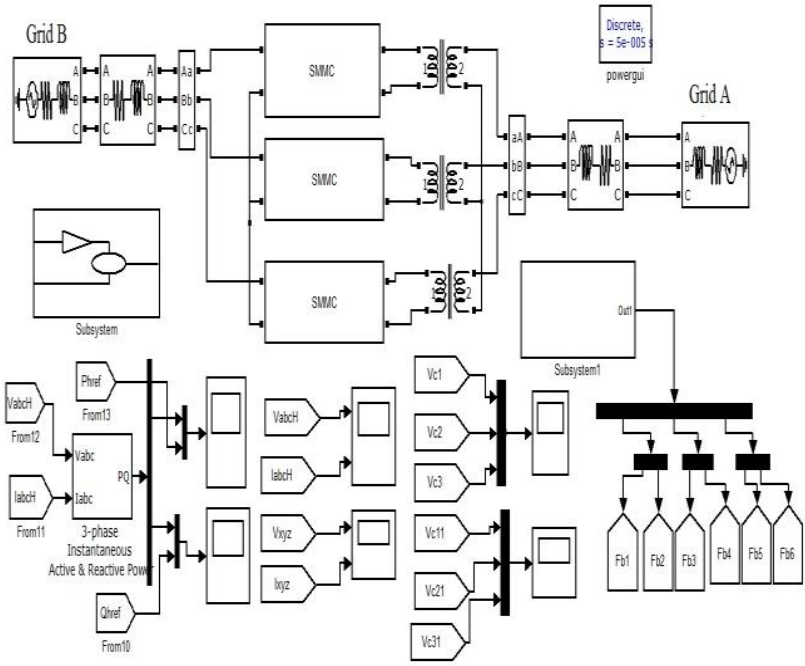

Fig. 4.1 Simulink diagram of three phase 7 - level SMMC

Fig .4.3 shows that Simulink diagram of subsystem. Fig. 4.4 shows that Simulink diagram of subsystem1. Fig. 4.5 shows that Simulink diagram of current controller.

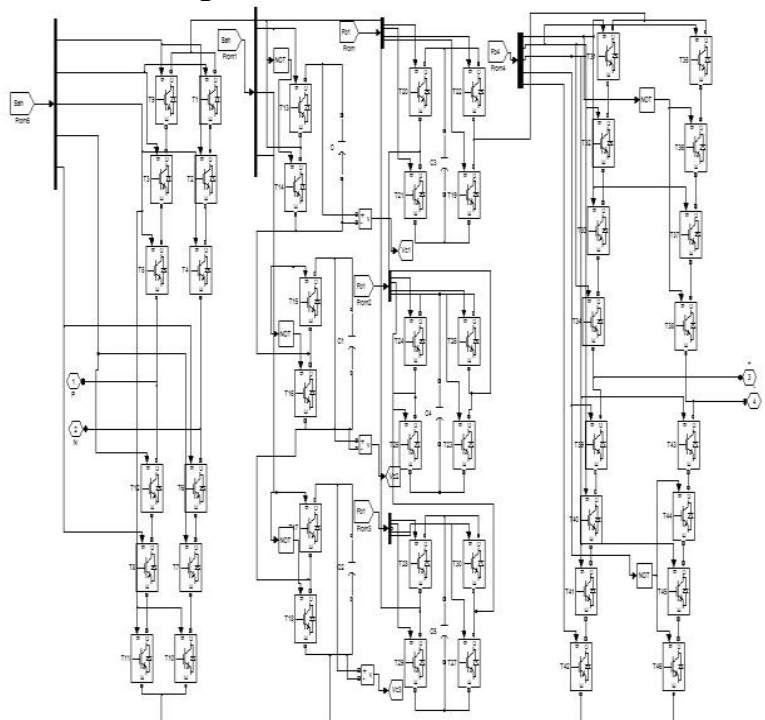

Fig. 4.2 Simulink diagram of Single phase 7-level SMMC

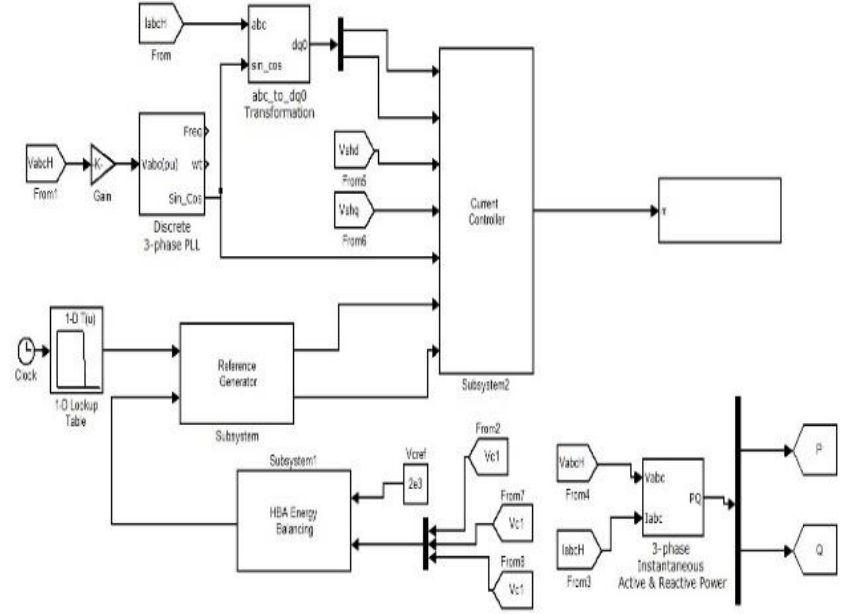

Fig. 4.3 Simulink diagram of subsystem

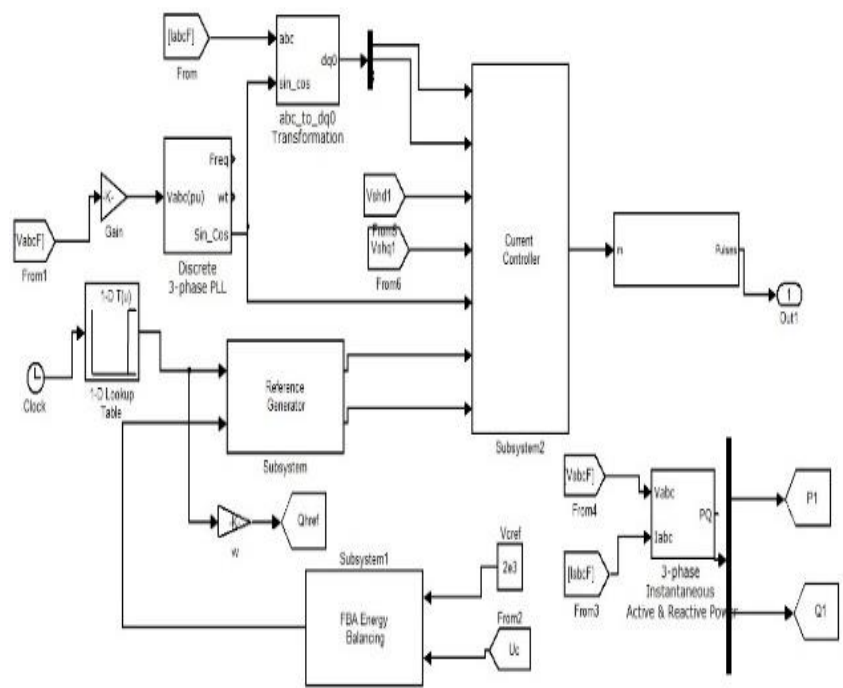

Fig. 4.4 Simulink diagram of subsytem1

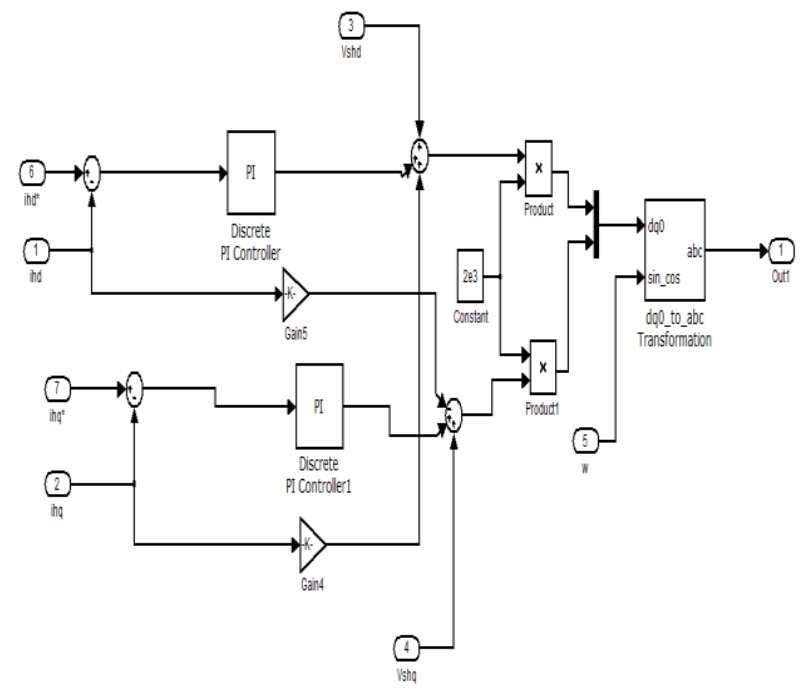

Fig. 4.5 Simulink diagram of current controller

Fig. 4.6 shows that input voltage and current waveforms on Grid A side. Fig. 4.7 shows that output voltage and current waveforms on Grid B side. Fig. 4.8 (a) \& (b) shows that capacitor Voltage waveforms of half bridge unfolder circuit and full bridge unfolder circuit. Fig. 4.9 shows that true and reactive power variations of a 7 - level SMMC. Fig. 4.10 shows the FFT analysis of output voltage waveform. 

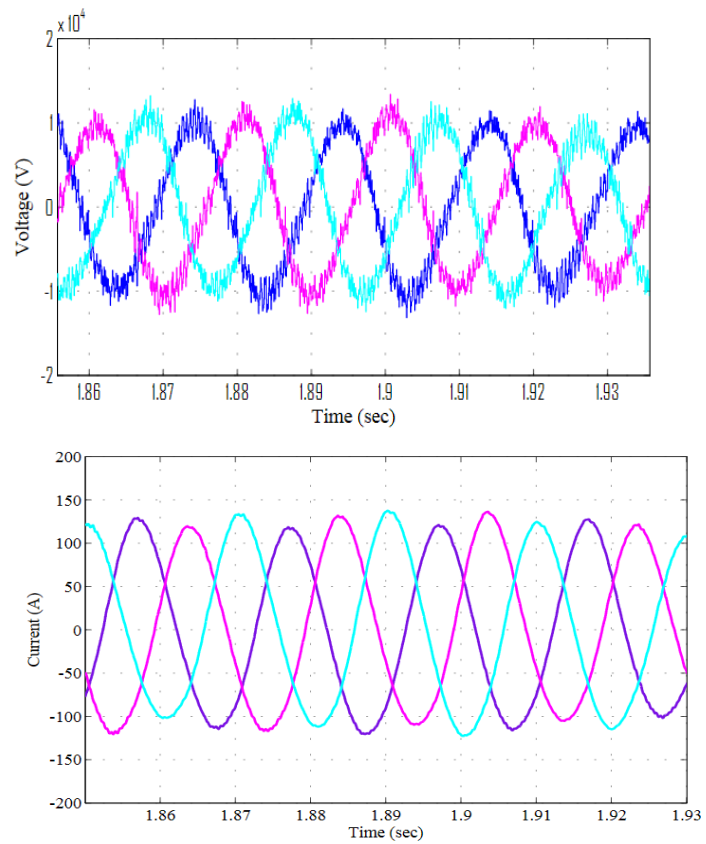

Fig. 4.6 Input voltage and current waveforms on Grid - A side.

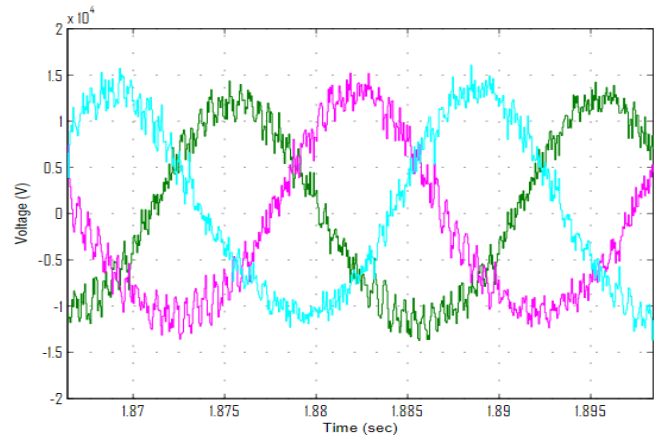

Fig. 4.7(a) Output voltage waveform on Grid - B side

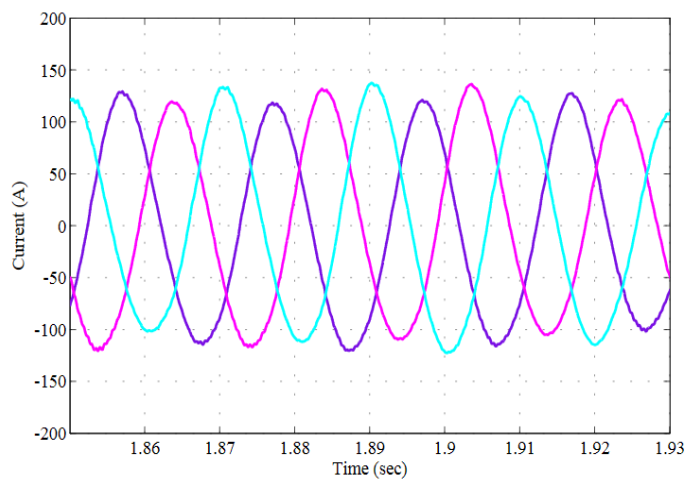

Fig. 4.7 (b) Output Current Waveforms on Grid - B side

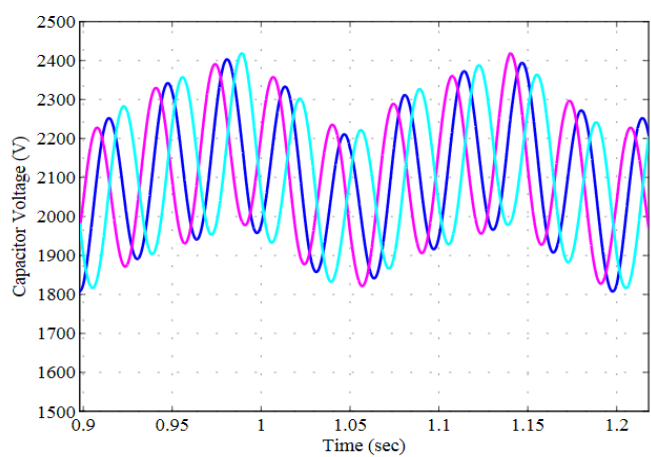

Fig. 4.8 (a) Capacitor voltage Waveforms of half bridge unfolder circuit

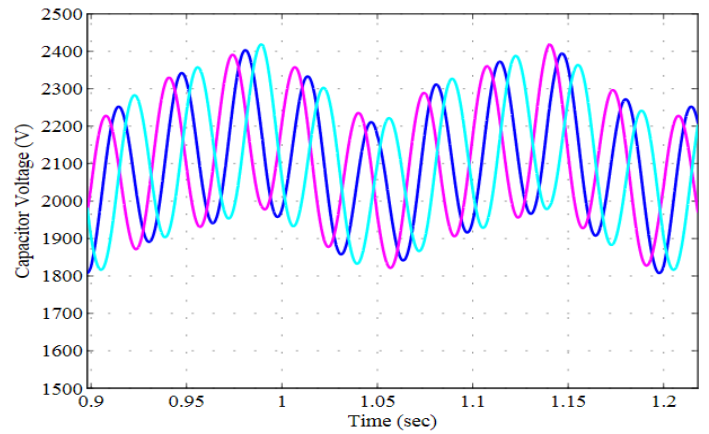

Fig. 4.8(b) Capacitor voltage waveforms of full bridge unfolder circuit

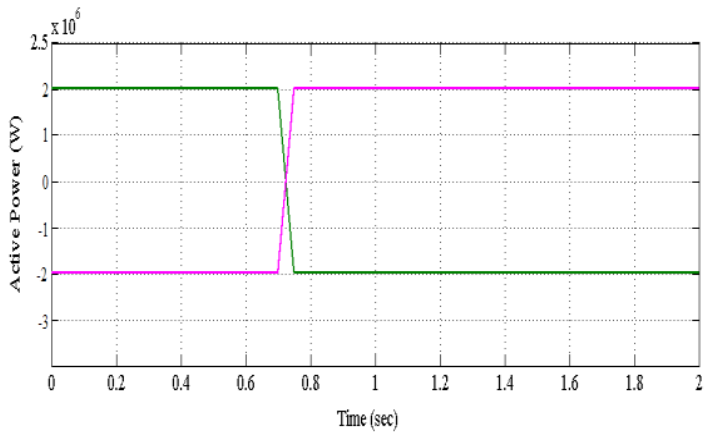

Fig. 4.9(a) True power variation of 7 - level SMMC

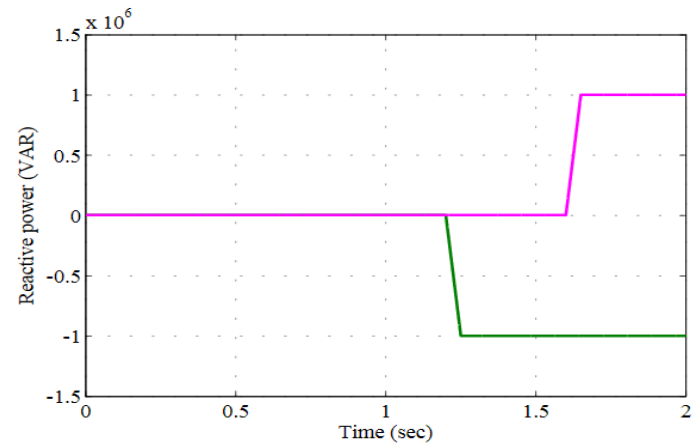

Fig. 4.9(b) Reactive power variation of 7 - level SMMC

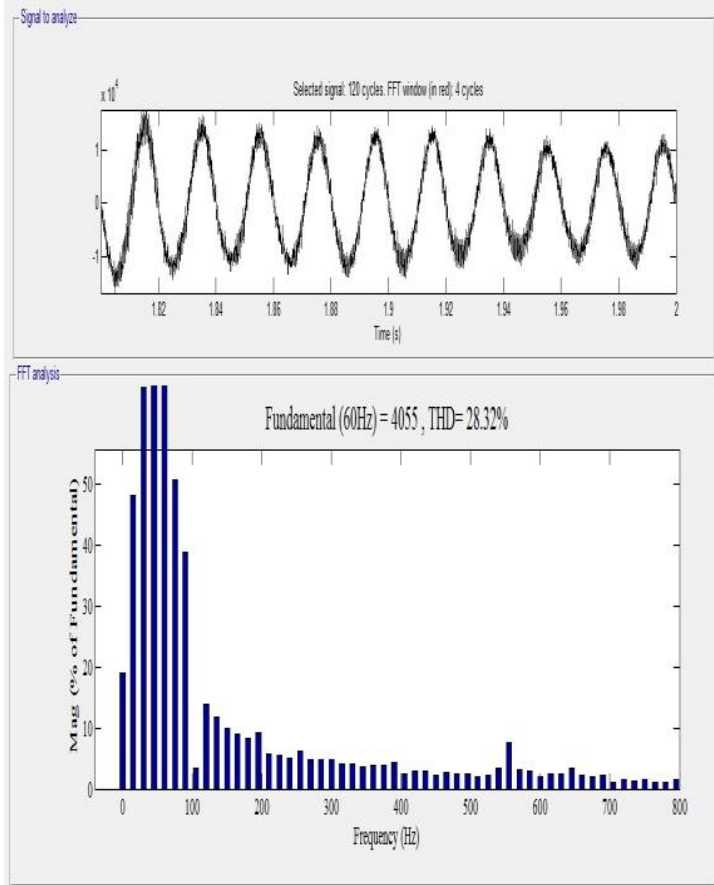

Fig. 4.10 FFT analysis of output voltage waveform 


\section{CONCLUSION}

In this paper, 7 - level AC - AC SMMC is proposed and control scheme with modified PWM technique is also discussed. In this converters more number of IGBT switches can operate under soft switching mode. So, losses in the converter is less. Hence efficiency of the converter has to be increased. By applying modified PWM technique to the converter, the oscillations and harmonics of the capacitor voltage waveform is reduced. From FFT analysis of 5-level and 7-level SMMC we can conclude that, number of levels of the converter increases THD will be reduced. The Simulation results attained from the MATLAB software shows the appropriateness of the 7 - level AC-AC SMMC.

\section{APPENDIX}

Simulation Parameters

\begin{tabular}{|l|l|}
\hline PARAMETER & RATING \\
\hline Grid - A Frequency & $50 \mathrm{~Hz}$ \\
\hline Grid - B Frequency & $60 \mathrm{~Hz}$ \\
\hline $\begin{array}{l}\text { Grid - A and Grid - B } \\
\text { Voltages }\end{array}$ & $20 \mathrm{KV}, 18.5 \mathrm{KV}$ \\
\hline Sub Module Capacitor & $4 \mathrm{mF}$ \\
\hline $\begin{array}{l}\text { Mean cell Capacitor } \\
\text { Voltage }\end{array}$ & $2000 \mathrm{~V}$ \\
\hline $\begin{array}{l}\text { Filter Grid } \\
\text { inductance }\end{array}$ & $5 \mathrm{mH}$ \\
\hline $\begin{array}{l}\text { Filter Grid } \\
\text { resistance }\end{array}$ & $10 \mathrm{~m} \Omega$ \\
\hline
\end{tabular}

\section{ACCKNOWLEDGEMENT}

I wish to thank Sri. M. ANKARAO M.Tech., (Ph.D), Assistant professor in dept. of EEE, JNTUA College of Engineering \& technology, Anantapur for his valuable guidelines throughout my project work and extended his support for the success of this project. I take this opportunity to convey my sincere thanks to my parents, friends and to all those who have directly and indirectly contributed for the successful completion of my project.

\section{REFERENCES}

[1] Lotfjou, Y. Fu, and M. Shahidehpour, "Hybrid AC/DC transmission expansion planning," IEEE Trans. Power Del., vol. 27, no. 3, pp. 1620-1628, Jul. 2012.

[2] S. A. Khajehoddin, P. K. Jain, and A. Bakhshai, "Cascaded multilevel converters and their applications in photovoltaic systems," in Proc. $2^{\text {nd }}$ Can. Sol. Buildings Conf., Calgary, AB, Canada, Jun. 2007, pp. 10-14.

[3] M. Saeedifard and R. Iravani, "Dynamic performance of a modular multilevel back-to-back HVDC system," IEEE Trans. Power Del., vol. 25 , no. 4, pp. 2903-2912, Oct. 2010.

[4] S. A. Khajehoddin, A. Bakhshai, and P. K. Jain, "A voltage balancing method and its stability boundary for five-level diode-clamped multilevel converters," in Proc. IEEE Power Electron. Spec. Conf., Orlando, FL, USA, Jun. 2007, pp. 2204-2208.

[5] S. A. Khajehoddin, A. Bakhshai, and P. K. Jain, "A simple voltage balancing scheme for m-level diode-clamped multilevel converters based on a generalized current flow model," IEEE Trans. Power Electron., vol. 23, no. 5, pp. 2248-2259, Sep. 2008.
[6] M. Marchesoni and P. Tenca, "Diode-clamped multilevel converters: A practicable way to balance DC-link voltages," IEEE Trans. Ind. Electron., vol. 49, no. 4, pp. 752-765, Aug. 2002.

[7] A. Lesnicar and R. Marquardt, "An innovative modular multilevel converter topology suitable for a wide power range," in Proc. IEEE Power Tech Conf., Bologna, Italy, Jun. 2003, pp. 272-277.

[8] W. Kawamura, K.-L. Chen, M. Hagiwara, and H. Akagi, "A low-speed, high-torque motor drive using a modular multilevel cascade converter based on triple-star bridge cells (MMCC-TSBC)," IEEE Trans. Ind. Appl., vol. 51, no. 5, pp. 3965-3974, Sep. 2015.

[9] M. Sztykiel, R. da Silva, R. Teodorescu, L. Zeni, L. Helle, and P. C Kjaer, "Modular multilevel converter modelling, control and analysis under grid frequency deviations," in EPE Joint Wind Energy and T\&D Chapters Seminar, 2013.

[10] R. Alaei, S. A. Khajehoddin, and W. Xu, "Sparse AC/AC modular multilevel converter," IEEE Trans. Power Del., vol. 31, no. 3, pp. 1195-1202, Jun. 2016

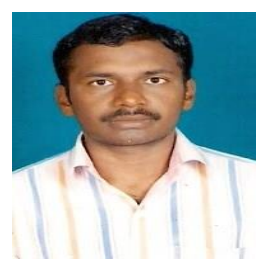

M. Anka Rao received M.Tech degree in power and industrial drives from JNTU College of engineering and technology, Anantapur in the year 2010. He is currently working as an Assistant professor in electrical and electronics department in JNTU College of engineering \& technology, Anantapur. He awarded a B.Tech degree in Electrical and Electronics Engineering from Andhra University in the year 2006. He is currently working towards the Ph.D degree in power and industrial drives at JNTU college of Engineering \& technology, Anantapur.

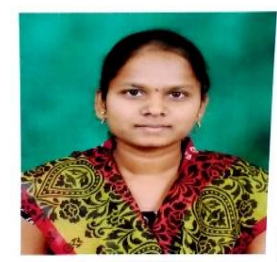

R. Mayuri received B.Tech degree in Electrical and Electronics Engineering from Rajeev Gandhi Memorial College of Engineering and Technology, Nandyala in the year 2016. She is currently working towards the M.Tech degree in Power and Industrial Drives in JNTU College of Engineering \& Technology, Ananatapur. 